\title{
Strategi Perencanaan Komunikasi Dakwah Masjid Peneleh Surabaya
}

\author{
A. Fikri Amiruddin Ihsani, ${ }^{1}$ Novi Febriyanti ${ }^{2}$ \\ 'UIN Sunan Ampel Surabaya²UIN Sunan Ampel Surabaya \\ 1'fikriamiruddin27@gmail.com, 2novikfbr@gmail.com
}

\begin{abstract}
This study discusses the da'wah communicationplanning strategy of the Peneleh Mosque in Surabaya. The purpose of this research is to describe, explain, and know the strategy of communication planning for the da'wah communication of the Peneleh Mosque in Surabaya and to describe, explain, and know the strategy for the communication planning of the Peneleh Mosque in Surabaya in a review of 'Talcott Parsons' functional structural theory. This research uses qualitative research methods with a descriptive approach. Data collection techniques used were observation, interviews, and documentation. The data that has been collected are then analyzed, compared, and combined to form a systematic, coherent and complete study result. In this research, it is found that; (1) In the communication planning strategy of the Peneleh Mosque in Surabaya, it takes the subject of preaching from outside, the message design continues the walisongo method, the media used is face-to-face, and the determination of the audience is the surrounding community. (2) In a review of Talcott Parsons' functional structural theory, the strategy for the communication planning of the Peneleh Mosque in Surabaya includes adaptation to the surrounding environmental conditions, achieving the goal of the message content of ritual and social piety, integration between the community, the mosque as a place of worship, and the tahfidz Islamic boarding school. Next, in maintaining the pattern, always carry out active and intensive communication with all existing structures and functions in the Peneleh Mosque area of Surabaya. Thus, it is hoped that the process of da'wah communication can be established effectively and efficiently.
\end{abstract}

Keywords: Strategy, Communication, Da'wah, Mosque.

\begin{abstract}
Abstrak
Penelitian ini membahas mengenai strategi perencanaan komunikasi dakwah Masjid Peneleh Surabaya. Adapun tujuan dari penelitian ini adalah untuk mendeskripsikan, menjelaskan, dan mengetahui strategi perencanaan komunikasi dakwah Masjid Peneleh Surabaya serta mendeskripsikan, menjelaskan, dan mengetahui strategi perencanaan komunikasi dakwah Masjid Peneleh Surabaya dalam tinjauan teori struktrual fungsional Talcott Parsons. Penelitian ini menggunakan metode penelitian kualitatif dengan pendekatan deskriptif. Teknik pengumpulan data yang digunakan adalah observasi, wawancara, dan dokumentasi. Data yang berhasil dikumpulkan kemudian dianalisis, dibandingkan, dan dipadukan sehingga terbentuk sebuah hasil kajian yang sistematis,padu, dan utuh. Dalam penelitian ini diperoleh hasil bahwa; (1) Dalam strategi perencanaan komunikasi dakwah Masjid Peneleh Surabaya mengambil subjek dakwah berasal dari luar, rancangan pesan meneruskan cara walisongo, media yang digunakan tatap muka, dan penentuan khalayaknya adalah masyarakat sekitar. (2) Dalam tinjauan teori struktural fungsional Talcott Parsons, strategi perencanaan komunikasi dakwah Masjid Peneleh Surabaya meliputi adaptasi dengan kondisi lingkungan sekitar, pencapaian tujuan isi pesan dakwah kesalehan ritual dan sosial, integrasi antara masyarakat, masjid sebagai tempat ibadah, dan pondok pesantren tahfidz. Berikutnya dalam pemeliharaan polanya selalu melakukan komunikasi aktif dan intensif dengan seluruh struktur dan fungsi yang ada di kawasan Masjid Peneleh Surabaya. Dengan demikian, diharapkan proses komunikasi dakwah dapat terjalin dengan efektif dan efisien.
\end{abstract}

Kata Kunci: Strategi, Komunikasi, Dakwah, Masjid.

JurnalKopis: Kajian Penelitian dan PemikiranKomunikasiPenyiaran Islam

Volume 03, Issue 02, Februari 2021 


\section{Pendahuluan}

Strategi perencanaan komunikasi tentusangat penting untuk menyuarakan atau mendoktrinkan suatu ajaran kepada masyarakat. Hal tersebut dikarenakan komunikasi sangat melekat dalam kehidupan sehari-hari. Komunikasi terjadi sebagaimana mestinya secara verbal maupun non-verbal. Sehingga harapannya komunikasi ini dapat serta merta menumbuh-kembangkan perjalanan peradaban umat manusia. Dalam hal ini, komunikasi juga disertai adanya perencanaan sehingga hasil yang diinginkan dapat tercapai dengan baik. Perencanaan komunikasi adalah sebuah upaya sistematis dan berkesinambungan untuk merealisasikan beberapa kebijakan komunikasi dengan cara mengorganisir kegiatan manusia pada usaha penggunaan sumber daya komunikasi secara efektif dan efisien. Perencanaan komunikasi menjelaskan proses dalam menyebarluaskan pesan yang tepat oleh komunikator kepada komunikan atau khalayak yang tepat, melalui saluran dan waktu yang tepat. Kedudukan perencanaan dalam komunikasi ialah berperan penting dalam mencapai kesuksesan suatu organisasi maupun lembaga. ${ }^{1}$

Sehingga kemudian dalam perkembangannya muncul komunikasi dakwah yang merupakan suatu proses penyampaian pesan atau gagasan yang bersumber dari individu atau kelompok satu kepada individu atau kelompok lainnya. Informasi atau isi muatan pesan tersebut bersumber dari ajaran al-Qur'an dan Hadis yang merupakan pedoman umat Islam, yang disampaikan dengan cara verbal maupun non-verbal yang bertujuan untuk mengubah sikap, pendapat, pandangan, maupun perilaku orang lain agar sesuai dengan ajaran Islam baik secara langsung atau lisan maupun tidak langsung, dalam artian menggunakan media. ${ }^{2}$

Dalamhalkomunikasi pasti juga disertai dengan perencanaan agar sesuai dengan target yang diharapkan. Perencanaan adalah proses penggagasan dan pengkondisian secara matang dari hal-hal yang harus dilaksanakan pada masa yang akan datang demi mencapai sebuah tujuan yang telah ditentukan. Sehingga perencanaan komunikasi merupakan suatu usaha yang sistematis dan berkesinambungan dalam beberapa hal untuk dapat merealisasikan berbagai kebijakan komunikasi dengan cara mengkondisikan aktivitas manusia dalam upaya penggunaan sumber daya komunikasi secara tepat dan efisien. ${ }^{3}$

Dalam suatu lembaga atau masjid terdapat adanya strategi atau perencanaan komunikasi khususnya dalam berdakwah. Masjid merupakan salah satu pranata agama yang terhubung dengan kehidupan spiritual, sosial, dan kultural umat Islam. Eksistensi masjid dipandang sebagai salah satu wujud dari keberadaan dan aspirasi umat Islam, terutama sebagai sarana peribadatan yang menduduki fungsi sentral bagi kehidupan masyarakat. ${ }^{4}$

Memahami masjid secara luas berarti memahaminya sebagai suatu instrumen sosial masyarakat yang tidak bisa dipisahkan dari masyarakat itu sendiri. Sejarah perkembangan Islam mengungkapkan secara garis besar masjid memiliki dua aspek, yakni sebagai tempat

\footnotetext{
${ }^{1}$ Ida Suryani Wijaya, "Perencanaan dan Strategi Komunikasi dalam Kegiatan Pembangunan," Jurnal Lentera, Volume 18, No. 01 (2015), 56.

${ }^{2}$ Wahyu Ilahi, Komunikasi Dakwah (Bandung: PT. Remaja Rosdakarya, 2010), 26.

${ }^{3}$ Hafied Cangara, Perencanaan dan Strategi Komunikasi (Jakarta: PT Raja Grafindo Persada, 2014), 24.

${ }^{4}$ Ari Saputra dan Bayu Mitra Adhyatma Kusuma, "Revitalisasi Masjid dalam Dialektika Pelayanan Umat dan Kawasan Perekonomian Rakyat,” Jurnal al-Idarah, Volume 01, No, 01 (2017), 2.
} 
ibadah dan sebagai tempat pembinaan umat. Setelah Islam mulai mengalami perkembangan, masjid mengalami proses adaptasi dan penyempurnaan baik dari segi corak maupun fungsinya. Masjid sendiri berasal dari bahasa Arab, sajada yang berarti tempat sujud atau tempat menyembah Allah. Bumi yang ditempati manusia merupakan masjid bagi kaum muslimin. Masjid secara sederhana adalah tempat orang berkumpul untuk melaksanakan sholat berjamaah, dengan tujuan meningkatkan solidaritas dan silaturrahmi di kalangan umat Islam. Di masjid pula tempat terbaik untuk menunaikan shalat subuh. ${ }^{5}$

Dalam perkembangannya, masjid tidak hanya hadir sebagai sarana ibadah saja, namun lebih dari itu masjid berkembang menjadi sebuah tempat untuk berbagai macam kegiatan misalnya manasik haji, resepsi pernikahan, seminar, workshop, dan lain sebagainya. Hal tersebut dikarenakan adanya perencanaan dan strategi yang diatur oleh pengelola atau takmir masjid yang bersangkutan. Pada zaman Rasulullah pun masjid sudah difungsikan sebagai tempat aktivitas sosial misalnya mengumpulkan zakat, infaq, dan sedekah baru kemudian disalurkan kepada orang yang membutuhkan. Karena itu, dalam masa Rasulullah, masjid memiliki peran yang sangat penting dalam berbagai kegiatan terutama yang terkait dengan persoalan sosial, sehinggapada masa itu masyarakat menjadi cinta pada masjid. ${ }^{6}$

Oleh karena itu, peneliti sangat tertarik untuk mengkaji secara lebih jauh dan mendalam mengenai bagaimana cara strategi perencanaan komunikasi dakwah pada salah satu masjid yang bersejarah dalam penyebaran ajaran Islam terutama di daerah Surabaya dan sekitarnya, yaitu Masjid Peneleh Surabaya. Dengan adanya unsur historis tersebut maka kemudian masjid ini pasti memiliki keunikan dan sesuatu yang menonjol untuk dapat dituliskan dalam perjalanan peradaban Islam di tanah Surabaya.

Adapun tujuan dari penelitian ini adalah untuk mendeskripsikan, menjelaskan, dan mengetahui strategi perencanaan komunikasi dakwah yang terdapat di Masjid Peneleh Surabaya serta mendeskripsikan, menjelaskan, dan mengetahui strategi perencanaan komunikasi dakwah Masjid Peneleh Surabaya apabila ditinjau dari teori struktural fungsional Talcott Parsons. Dengan demikian, diharapkan karya tulis ini memberi pemahaman mengenai strategi perencanaan komunikasi dakwah Masjid Peneleh Surabaya secara komprehensif. Kemudian juga sebagai sumbangsih pemikiran dalam khazanah keilmuan masyarakat untuk pengembangan ilmu terkait. Selain itu, karya tulis ini bisa memberikan informasi tambahan atau mungkin sebagai pembanding bagi peneliti atau penulis lain dalam persoalan terkait dan sebagai pengingat bahwa dakwah itu memiliki strategi dan perencanaan komunikasi yang matang.

\section{Metode}

Dalam penelitian ini peneliti menggunakan metode penelitian kualitatif dengan pendekatan deskriptif. Oleh karena itu, teknik pengumpulan data yang digunakan adalah observasi, wawancara, dan dokumentasi. Hasil observasi, wawancara, dan dokumendokumen yang berhasil dikumpulkan kemudian dianalisis, dibandingkan, dan dipadukan sehingga terbentuk sebuah hasil kajian yang sistematis, padu, dan utuh. Sehingga penulis tidak hanya mengumpulkan, menuliskan, dan melaporkannya dalam bentuk kutipan-

${ }^{5}$ Mohammad E. Ayyub, Manajemen Masjid: Petunjuk Praktis Bagi Para Pengurus/Penulis (Jakarta: Gema Insani Press, 2001), 1-2.

${ }^{6}$ Ahmad Yani, Menuju Masjid Ideal (Jakarta: LP2SI, 2001), 14.

JurnalKopis: Kajian Penelitian dan PemikiranKomunikasiPenyiaran Islam

Volume 03, Issue 02, Februari 2021 
kutipan mengenai sejumlah data yang dilaporkan dalam penelitian, melainkan hasil analisis terhadap data yang diperoleh tersebut.

Sehingga dalam hal ini, analisis data penelitian kualitatif merupakan upaya yang dilakukan dengan jalan bekerja dengan data-data, mengorganisasikan data, memilah data menjadi satu kesatuan sehingga dapat dikelola, dipadukan, mencari dan menemukan pola, menemukan apa yang penting dan apa yang bisa dipelajari. Kemudian memutuskan apa yang sekiranya dapat disampaikan dengan baik dan mudah dipahami oleh orang lain.

\section{Hasil dan Pembahasan}

\section{Profil Masjid Peneleh Surabaya}

Secara administratif Masjid Peneleh berlokasi di jalan Achmad Djais Gang Peneleh V No. 41 Kelurahan Peneleh, Kecamatan Genteng, Kota Surabaya, Provinsi Jawa Timur. Lokasi masjid ini tidak jauh dari kediaman HOS Cokroaminoto yang berada di Gang Peneleh VII, dan juga berjarak sekitar 400 meter dari Kerhof atau pemakaman orang Belanda. Secara historis, Masjid yang didirikan di Peneleh ini masih begitu sederhana meskipun sudah lebih luas dan bagus apabila dibandingkan dengan masjid pertama (Langgar Kembang Kuning) yang dibangun di Surabaya. Sehingga Masjid Peneleh adalah tempat ibadah umat Islam yang kedua didirikan oleh Raden Rahmat beserta rombongannya.

Ketua Masjid Peneleh mengungkapkan bahwa persoalan sejarah tidak ada buku atau bukti otentik yang menjelaskan, namun berdasarkan cerita yang ada secara turun temurun. Berdasarkan cerita yang beradar di kalangan masyarakat memang dibangun oleh Raden Rahmatullah (Sunan Ampel). Sedangkan bangunannya sedari awal tidak jauh berbeda dengan yang ada sekarang. Hal tersebut dikarenakan renovasi yang dilakukan hanya berkisar pada pembaruan lapisan cat dan penambahan serambi masjid saja. ${ }^{7}$

Pada tahun 1800, Masjid peninggalan Raden Rahmat ini mengalami renovasi. Pada saat renovasi masjid tersebut bangunan yang terdapat di dalam Masjid tetap dipertahankan seperti aslinya dengan ditopang oleh sepuluh tiang penyangga dari kayu jati, dan langitlangitnya juga terbuat dari kayu jati. Menurut Ketua Takmir Masjid Peneleh, bangunan Masjid ini sangat unik dikarenakan berbentuk seperti perahu terbalik yang menghadap kiblat dan disokong oleh 10 tiang kayu. 10 tiang tersebut mempunyai filosofi sokong guru (Malaikat) dan salah satu tiangnya ditengarahi dahulu digunakan sebagai patokan penentuan arah kiblat. Lebih lanjut ia menjelaskan bahwa menurut cerita yang beredar apabila dilihat menggunakan mata batin, tiang tersebut satu garis lurus dengan Ka’bah di Kota Makkah. ${ }^{8}$

Sedangkan pada bagian luar Masjid, dibuatkan dinding yang tinggi dengan keberadaan pintu dan jendela yang besar. Sehinggaapabila dilihat secara sekilas bangunan ini mirip dengan gaya arsitektur yang ada di Gedung Grahadi yang berlanggam Indische Empire. Pada tahun 1945, pada masa awal kemerdekaan kubah Masjid Peneleh pernah terkena tembakan meriam Belanda dari arah Jembatan Merah. Kubahnya tidak hancur, akan tetapi di sisi

${ }^{7}$ Sofyan, Wawancara oleh Penulis, 08 April 2019.

${ }^{8}$ Sofyan, Wawancara oleh Penulis, 08 April 2019.

JurnalKopis: Kajian Penelitian dan PemikiranKomunikasiPenyiaran Islam Volume 03, Issue 02, Februari 2021 
timurnya sedikit mengalami kerusakan kemudian langsung diperbaiki. Pada tahun 1970, serambi Masjid mengalami perluasan tanpa mengubah ornamen dalam maupun keaslian Masjid tersebut. Apabila dilihat secara sekilas, tembok bangunan Masjid Peneleh ini kualitasnya mirip dengan Masjid Agung Ampel. Sehingga pada saat ini kemegahan Masjid seluas $950 \mathrm{~m}$ persegi ini tidak diragukan lagi. Sehingga keelokan Masjid ini terpancar setelah dilakukan renovasi pada tahun 1800 dengan dipasangi hiasan kaca-kaca patri pada setiap ventilasi di sela-sela atap.

Seiring dengan perkembangan zaman, di lingkungan Masjid ini semakin berubah menjadi pemukiman yang padat. Padahal, pada semula Masjid ini bisa disaksikan dari tepi Kali Mas, akan tetapi saat ini sudah terhimpit oleh bangunan rumah milik warga. Sehingga dalam hal ini menyebabkan pamornya kalah dengan Masjid Rahmat yang ada di Kembang Kuning maupun Masjid Agung Ampel. Padahal, dalam sejarahnya sampai pada tahun 1900an daerah ini masih menarik untuk disinggahi, namun sekarang seolah-olah terbenam. Bahkan, masyarakat Surabaya sendiri jarang yang mengetahuinya. Kampung Peneleh tergolong kampung lama sudah ramai sejak dahulu kala, dikarenakan dekat dengan Kali Mas sebagai lalu lintas perdagangan pada saat itu. Selain itu, juga alasan Ali Rahmatullah (Sunan Ampel) datang ke Peneleh dikarenakan di Peneleh sendiri sudah terdapat sebuah komunitas muslim. Hal tersebut diperkuat dengan adanya makam Mbah Campa yang berada di Peneleh Gang IX. ${ }^{9}$

Padahal, sebenarnya apabila kawasan Kampung Peneleh direvitalisasi secara komprehensif dan integratif, maka tidak menutup kemungkinan kawasan kuno tersebut dapat menjadi potensi wisata sejarah andalan bagi Kota Surabaya. Dikarenakan situs kuno Kampung Peneleh ini sarat dengan nilai sejarah yang ditandai oleh bertebarannya bangunan kuno yang terdapat di kampung ini. Mulai dari adanya pemukiman kuno, bangunan publik bergaya kolonial, dan Masjid peninggalan seorang Wali yang saat itu bermukim di Peneleh beserta rombongannya. Secara kronologis dalam pendirian Masjid Peneleh, Ketua Takmir Masjid mengungkapkan bahwa dahulu Sunan Ampel datang ke Jawa untuk menengok kakaknya yang dipersunting oleh Raja Majapahit pada saat itu. Sehingga kemudian oleh kerajaan Majapahit, Sunan Ampel diberikan sebuah tanah yang dahulu bernama Ampel Denta. Ampel Denta merupakan sebutan tanah perdikan (tanah yang dihadiahkan oleh seorang raja kepada seseorang yang berjasa pada kerajaan). Maka dari perjalanan dari Majapahit yang berpusat di daerah Mojokerto saat ini, Raden Rahmat mengarungi sungai brantas untuk sampai di Surabaya. Sebelum sampai di Ampel, ia mampir di Kembang Kuning dan kemudian tertarik dengan salah seorang putri, maka menikahlah Sunan Ampel di sana dan mendirikan sebuah surau. Selain bukti adanya Masjid Rahmat, terdapat juga makam Mbah Karimah yang merupakan mertua dari Sunan Ampel, yang setiap tahun diadakan Haul di Masjid Rahmat Kembang Kuning. ${ }^{10}$

Masjid Peneleh merupakan salah satu saksi bisu penyebaran Islam di Surabaya. Di dalam Masjid Peneleh ini ornamen dari kayu jati terasa begitu kental, tidak hanya tiang penyangga saja, melainkan langit-langit masjid juga tak lepas dari aksen kayu jati. Langitlangit bangunan dihiasi oleh tulisan Arab yang bertuliskan nama empat sahabat Nabi, yakni Abu Bakar, Umar bin Khattab, Usman bin Affan, dan Ali bin Abi Thalib. Kemudian juga

9Sofyan, Wawancara oleh Penulis, 08 April 2019.

${ }^{10}$ Sofyan, Wawancara oleh Penulis, 08 April 2019.

JurnalKopis: Kajian Penelitian dan PemikiranKomunikasiPenyiaran Islam

Volume 03, Issue 02, Februari 2021 
terdapat 25 ventilasi yang mengelilingi tembok masjid, yang juga bertuliskan aksara Arab dengan dihiasi 25 nama Nabi dan Rasul. Tak banyak catatan atau refernsi mengenai masjid ini, namun masyarakat setempat mempercayai bahwasannya Masjid Peneleh ini dibangun oleh Sunan Ampel pada tahun 1421 M atau lebih tua apabila dibandingkan Masjid Agung Ampel sendiri.

Di masjid ini juga masih menggunakan jam istimewa yang digunakan sebagai pedoman waktu sholat. Jam istimewa merupakan petunjuk waktu yang mengandalkan arah condong matahari. Selain itu, juga masih terdapat cerita mistis tepatnya di tempat jamaah perempuan yang terdapat sebuah sumur bekas, luas sumur tersebut hanya berkisar satu buah keramik sehingga selalu tertutup rapat. Hinggasaat ini sumur tersebut masih banyak diburu lantaran ada kepercayaan yang berkembang di masyarakat akan khasiat yang ada di dalamnya. Kemudian juga pembangunan masjid ini kono dilatar-belakangi oleh daerah Peneleh yang merupakan daerah ramai. Hal tersebut dikarenakan Kampung Peneleh berada di sisi timur Kali Mas, sungai yang menjadi pusat lalu lintas perairan saat itu. Sehingga memudahkan Sunan Ampel dalam menyiarkan agama Islam.

Pada zaman kolonial, masjid ini juga dijadikan sebagai markas oleh Laskar Hizbullah untuk mengusir penjajah. Untuk mengelabui musuh, dari luar masjid ini tampak seperti tempat beribadah yang berfungsi sebagaimana mestinya. Padahal, di dalamnya digunakan sebagai tempat menyimpan dokumen dan diskusi Laskar Hizbullah. Bahkan, apabila ada musuh yang lewat, tidak mudah menangkapnya dikarenakan kawasan tersebut dari dahulumerupakan daerah padat penduduk. Meskipun bangunan masjid ini termasuk peninggalan sejarah, akan tetapi pengurus masjid tidak berencana memasukkannya sebagai cagar budaya. Hal tersebut dikarenakan masjid ini dibangun dan direnovasi dari swadaya masyarakat. Ketua Takmir Masjid Peneleh juga membenarkan bahwa masjid ini lebih memilih dikelola oleh swadaya masyarakat, dikarenakan apabila masjid ini dimasukkan sebagai aset cagar budaya, maka otomatis pengelolaannya diambil alih oleh pemerintah. Sehingga kemudian efeknya masyarakat hanya akan menjadi tamu di masjid ini dan tentu saja sinergi antara masjid dan masyarakat akan hilang begitu saja. ${ }^{11}$

Di dalam masjid juga terdapat bedug yang berdiameter kurang lebih satu meter dan mempunyai panjang dua meter. Bedug tersebut ditemukan hanyut di sekitar Kalimas, yang tepat berada di depan kampung Peneleh dan terhenti di aliran Kalimas. Kemudian warga mengambilnya dan membawanya ke Masjid Peneleh. Akan tetapi, pada awalnya bedug tersebut tidak digunakan dikarenakan rencananya akan diletakkan di Masjid Agung Ampel. Sehingga kemudian bedug tersebut dipindah ke Masjid Agung Ampel. Namun, ketika bedug digunakan suaranya terdengar tidak nyaring. Sehingga bedug dipindah ke Masjid Kemayoran di kawasan Indrapura, dan saat digunakan hasilnya juga tidak sempurna sehingga bunyinya tidak begitu nyaring. Pada akhirnya, bedug dikembalikan dan dicoba di Masjid Peneleh, anehnya saat dicoba di Masjid Peneleh suara bedug berubah menjadi keras dan nyaring berbeda dari sebelumnya. Sehingga kemudian warga menggunakannya di Masjid Peneleh.

\footnotetext{
${ }^{11}$ Sofyan, Wawancara oleh Penulis, 08 April 2019.
} 


\section{Strategi Perencanaan Komunikasi Dakwah Masjid Peneleh Surabaya}

Strategi perencanaan komunikasi dakwah merupakan suatu panduan perencanaan komunikasi dengan berbagai konsep dan manajemen untuk mencapai sebuah target yang telah ditetapkan. Sedangkan komunikasi dakwah sendiri adalah suatu ajakan yang dilakukan oleh seorang komunikator yang dalam hal ini subjek dakwah, untuk mengajak mad'u atau komunikan dakwah dalam hal inipara jama'ah. Komunikasi dakwah tersebut dapat dilakukan dengan komunikasi verbal maupun non-verbal yang bertujuan menyampaikan kebajikan. Dalam hal ini, pemilihan strategi dalam perencanaan komunikasi dakwah merupakan suatu langkah krusial dengan penanganan yang teliti, sebab strategi yang diterapkan akan banyak berpengaruh terhadap hasil yang akan diperoleh pada kemudian hari. Sehingga dapat dikatakan bahwasannya keberhasilan proses komunikasi dakwah sangat berpengaruh pada strategi apa yang disusun sebelumnya. ${ }^{12}$ Sedangkan faktor yang mendukung keberhasilan strategi komunikasi antara lain yaitu mengenali sasaran komunikasi, pemilihan media komunikasi, pengkajian tujuan pesan komunikasi, dan peranan komunikator dalam komunikasi. ${ }^{13}$

Perencanaan dalam manajemen merupakan perumusan rencana dan strategi yang akan dilaksanakan dalam suatu aktivitas dengan tujuan yang sama. ${ }^{14}$ Untuk mendukung kelancaran tercapainya tujuan dalam strategi perencanaan komunikasi dakwah, maka terdapat beberapa hal yang perlu diperhatikan di antaranya ada unsur-unsur seperti komunikator, komunikan yang dituju, media yang dipilih, dan pesan dakwah. Maka dari kesemuanya itu pada akhirnya akan membentuk sebuah proses dakwah yang sesuai dengan tujuan yang telah direncanakan. Strategi perencaraan komunikasi dakwah yang terdapat di Masjid Peneleh Surabaya di antaranya sebagai berikut. Pertama, komunikator. Komunikator adalah pihak yang menyampaikan pesan atau dalam hal ini seorang da'i (subjek dakwah). Sehingga komunikator mempunyai peran sentral dalam proses komunikasi, sebagaimana dalam proses dakwah di Masjid Peneleh sendiri yang sesuai dengan program dan rencana dakwah yang sudah disiapkan. Sedangkan komunikator dalam dakwah adalah orang-orang yang memang mempunyai kemampuan serta kredibilitas mengenai keagamaan yang disesuaikan berdasarkan program dakwah yang dilaksanakan.

Pemilihan komunikator yang selektif tentu saja akan sangat mempengaruhi peforma dan menumbuhkan kepercayaan dari mad'u atau penerima dakwah. Sehingga komunikator tersebut yang dalam hal ini adalah da'i akan dipilih berdasarkan pengetahuan dan latar belakang yang sesuai dengan budaya dan ajaran yang berkembang di masyarakat. Yang mana di Masjid Peneleh ini diadakan pengajian umum rutin setiap bulannya. Ketua Takmir Masjid Peneleh mengungkapkan bahwa untuk pengajian umum atau majelis taklim narasumbernya bergantian, terkadang mubaligh atau bisa juga mubalighah. Jadi, di Masjid Peneleh ini dalam berbagai aktivitas dakwahmemang mencari komunikator dari luar yang

${ }^{12}$ Halilul Khairi, Dinamika Pelaksanaan Urusan di Bidang Persandian Pemerintah Daerah (Jakarta: Yayasan Pustaka Obor Indonesia, 2017), 67.

${ }^{13}$ Amien Wibowo, "Strategi Komunikasi Dakwah (Strategi Komunikasi Dakwah Majelis Dzikir dan Sholawat Jamuro Surakarta)," Universitas Muhammadiyah Surakarta (2015), (http://eprint.ums.ac.id/35975/).

${ }^{14}$ Mochtar Effendi, Manajemen: Suatu Pendekatan Berdasarkan Ajaran Islam (Jakarta: Bharata Karya Aksara, 1986), 76.

JurnalKopis: Kajian Penelitian dan PemikiranKomunikasiPenyiaran Islam

Volume 03, Issue 02, Februari 2021 
memang memenuhi serta sesuai dengan kapasitas dikarenakan pada hari rabu, jum'at, dan sabtu setelah shalat subuh diadakan kajian tafsir Fiqih, Riyadussholihin, dan tafsir hadist. Seperti yang diungkapkan oleh Ketua Takmir Masjid Peneleh bahwa untuk pembicaranya mengambil narasumber dari luar semua, di antaranya ada yang namanya Ustadz Abdullah. ${ }^{15}$

Dalam hal pemilihan komunikator dakwahnya, pengurus Masjid Peneleh mengambil narasumber dari luar yang memang sudah mumpuni secara kualitas atau kapasitasnya sehingga track record-nya pun sudah jelas adanya. Sehingga harapannya ketika nanti menyampaikan pesan kepada masyarakat tidak ada keraguan mengenai pesan yang disampaikan tersebut. Sehingga program yang direncanakan diharapkan dapat memberi output yang sesuai dengan target yang dikonsepkan sedari awal. Selain mendatangkan narasumber dari luar yang kompeten, Takmir Masjid Peneleh juga memanfaatkan sumber daya manusia yang ada di Pondok Pesantren Tafsir yang berada tepat di depan Masjid Peneleh. Selain itu, khusus untuk pengelolaan TPQ, Masjid Peneleh juga bekerjasama dengan Pondok Pesantren yang diasuh oleh Kyai Ihya' yang berada di daerah Ketintang, Surabaya.

Pada hari-hari besar Islam biasanya Masjid Penelehbanyak mendatangkan alim ulama termasyur yang berhaluan ablussunnah wal jama'ah seperti halnya Gus Ali pengasuh Pondok Pesantren Bumi Sholawat Sidoarjo dan Gus Muwafiq dari Yogyakarta. Namun, untuk waktunya biasanya masih perlu kesepakatan lebih lanjut, hal tersebut dikarenakan para narasumber memiliki kesibukan yang padat. Sehingga untuk waktunya biasanya akan dikomunikasikan lebih lanjut. Sehingga dalam hal ini, diperlukan pengorganisasian sebagai suatu proses penentuan pengelompokkan dan pengaturan berbagai macam kegiatan, menyediakan peralatan yang dibutuhkan, menetapkan peran yang secara relatif didelegasikan kepada setiap individu yang akan melakukan kegiatan-kegiatan tersebut. ${ }^{16}$

Kedua, rancangan pesan. Pesan dakwah yang dikembangkan di Masjid Peneleh memiliki tujuan untuk mempertahankan corak keberagamaan yang dibawa oleh para wali termasuk Sunan Ampel yang merupakan pendiri Masjid Peneleh. Sehingga memang kental sekali dengan corak ahlussunnah wal jama'ah yang identik dengan Nahdlatul Ulama. Sehingga untuk rancangan pesan ini bersumber dari kitab-kitab klasik yang juga digunakan oleh ulama-ulama terdahulu antara lain mengkaji mengenai tafsir Fiqih, tafsir Riyadus sholihin, tafsir Hadist, Ihya' Ulumuddin, dan tak lupa kitab al-Hikam karya Ibn Ath-Thaillah alIskandari. Dalam pelaksanaannya dilakukan setelah lembaga atau organisasi mempunyai perencanaan dan pengorganisasian dengan mempunyai struktur organisasi termasuk tersedianya personil sebagai pelaksana sesuai kebutuhan kerja yang dibentuk. Pelaksanaan meliputi aktivitas-aktivitas yang diperlukan untuk jabatan-jabatan yang ada dalam struktur organisasi, dan mengarahkan serta menyalurkan perilaku manusia ke arah tujuan-tujuan. ${ }^{17}$

Untuk kajiannya dilaksanakan pada waktu yang beranekaragam antara lain untuk kajian Ihya' Ulumuddin dilaksanakan setiap hari senin setelah subuh, tafsir Fiqih dilaksanakan setiap hari rabu setelah subuh, tafsir Riyadus sholihin dilaksanakan setiap hari

\footnotetext{
${ }^{15}$ Sofyan, Wawancara oleh Penulis, 08 April 2019.

${ }^{16}$ M. Masibuan, Manajemen Dasar, Pengertian dan Masalab (Jakarta: Bumi Aksara, 2007), 119.

${ }^{17}$ G. R. Terry dan L. W Rue, Dasar-dasar Manajemen (Jakarta: Bumi Aksara, 1996), 10.
} 
jum'at setelah subuh, tafsir Hadist setiap hari sabtu setelah subuh, al-Hikam setiap minggu pertama setiap bulan pukul 08.00 pagi, dan juga biasanya diadakan istighosah setelah maghrib pada hari jum'at legi. Untuk tebih detailnya akan dirangkum di sebuah tabel sebagai berikut.

Tabel 1Pengajian Rutin Masjid Peneleh

\begin{tabular}{cccc}
\hline No. & Hari & Waktu & Materi \\
\hline 01. & Senin & Setelah Subuh & Ihya' Ulumuddin \\
02. & Rabu & Setelah Subuh & Tafsir - Fiqih \\
03. & Jum'at & Setelah Subuh & Tafsir - Riyadussholihin \\
04. & Sabtu & Setelah Subuh & Tafsir - Hadist \\
05. & Minggu I & Pukul 08.00 WIB & Al-Hikam \\
06. & Jum'at Legi & Setelah Maghrib & Istighosah
\end{tabular}

Hal tersebut di atas sesuai dengan apa yang diungkapkan oleh Ketua Takmir Masjid Peneleh Surabaya yang menjelaskan bahwa di Masjid Peneleh terdapat aktivitas dakwah rutin harian, bulanan, dan tahunan. Pertama terdapat pengajian tafsir yang dilaksanakan setiap selepas sholat subuh. Berikutnya terdapat juga model pengajian umum atau ceramahceramah agama yang dilaksanakan oleh majelis taklim satu bulan sekali pada hari minggu ketiga setiap bulan. Kemudian pada hari senin-jum'at juga terdapat TPQ untuk kalangan usia anak-anak. Selain itu juga ada kajian kitab al-Hikam setiap bulan pada minggu pertama. $^{18}$

Jadi, untuk rancangan pesan dakwah sudah diatur dan direncanakan dengan sedemikian rupa agar tepat sasaran. Karena itu, terdapat berbagai kajian dan kegiatan yang telah dijelaskan di atas. Seperti halnya tafsir fiqih untuk mempelajari tentang hukum-hukum ajaran agama Islam sebagai dasar, hingga kemudian juga terdapat kajian al-Hikam yang identik dengan ilmu hakikat dan kebijaksanaan. Sehingga dengan adanya berbagai kajian tersebut, diharapkan nantinya masyarakat dapat menyeimbangkan antara kesalehan ritual dan kesalehan sosial. Selain itu, juga terdapat aktivitas-aktivitas lain yang juga rutin dilaksanakan sesuai dengan yang dijelaskan oleh Ketua Takmir Masjid Peneleh bahwa pada hari minggu setiap bulan pertama ba'da zuhur ada istighosah dan sholawat yang diasuh oleh Ustadz Fadhol. Partisipasi masyarakat terkait sholat lima waktu maupun kegiatan yang lainnya sangat tinggi. Berikutnya selepas maghrib setiap hari minggu juga diadakan sholawat Nabi, hal tersebut dikarenakan Masjid Peneleh memang identik dan kental sekali dengan budaya organisasi Nahdlatul Ulama. ${ }^{19}$

Ketiga, penggunaan media. Dalam penggunaan media sendiri, Masjid Peneleh ini masih menggunakan cara-cara tradisional dan klasik. Hal tersebut dikarenakan Masjid Peneleh ini banyak dikelola dan diberdayakan dengan cara swadaya masyarakat. Ketua Takmir Masjid Peneleh menjelaskan bahwa untuk takmir dan kepengurusan masjid ada orang dari luar masyarakat sekitar, akan tetapi mayoritas masyarakat yang hidup di sekitar masjid sendiri. Hal tersebut dikarenakan untuk mempermudah monitoring dan evaluasi. Sehingga butuh kecepatan dalam bekerjasama dan dalam merespon sebuah aktivitas serta banyak kemungkinan lain yang terjadi pada kemudian hari. ${ }^{20}$

18Sofyan, Wawancara oleh Penulis, 08 April 2019.

${ }^{19}$ Sofyan, Wawancara oleh Penulis, 08 April 2019.

${ }^{20}$ Sofyan, Wawancara oleh Penulis, 08 April 2019.

JurnalKopis: Kajian Penelitian dan PemikiranKomunikasiPenyiaran Islam

Volume 03, Issue 02, Februari 2021 
Dikarenakan masjid ini berada di tengah-tengah sebuah perkampungan dan aksesnya harus masuk melalui gang terlebih dahulu, dalam artian tidak berada di pinggir jalan raya yang memungkinkan untuk disinggahi oleh tamu dari luar. Karena itu, masjid ini masih menggunakan media-media tradisional dalam berdakwah, yakni dengan memanfaatkan keberadaan masjid dan dengan media langsung atau bertatap muka. Media langsung ini merupakan media yang cukup efektif dikarenakan adanya interaksi langsung antara komunikator kepada para jama'ah. Sehingga dengan media langsung atau bertatap muka ini, maka diharapkan jama'ah yang mengikuti kegiatan tersebut dapat dengan mudah memahami isi pesan dakwah yang disampaikan. Dalam hal ini, juga diperlukan pengawasan untuk mengawasi kemajuan pencapaian dan sasaran serta mengambil tindakan korektif apabila diperlukan. ${ }^{21}$

Selain itu, khusus untuk media dan metode dakwah untuk kalangan anak-anak, dalam artian tingkat TPQ. Masjid Peneleh menggunakan metode dan cara yang khusus dalam pengajarannya seperti yang dijelaskan oleh Takmir Masjid Peneleh bahwa kepengurusan masjid memiliki banyak relasi atau kerjasama dengan beberapa Pondok Pesantren, antara lain Pondok Pesantren yang ada di daerah Ketintang yang diasuh oleh Kyai Ihya'. Sehingga dalam hal ini, untuk mengelola TPQ memang ada metode pengajaran yang khusus. ${ }^{22}$

Keempat, penentuan khalayak. Penentuan khalayak merupakan hal yang sangat penting dalam strategi perencanaan komunikasi dakwah. Hal tersebut dikarenakan isi pesan akan dapat diterima dengan baik apabila tepat kepada sasaran yang dituju. Target sasaran atau khalayak dalam berbagai kegiatan dakwah yang dilaksanakan di Masjid Peneleh Surabaya adalah masyarakat kampung Peneleh yang tentu saja tinggal di sekitar Masjid Peneleh. Sehingga dalam hal ini, pihak takmir atau pengurus masjid memfasilitasi masyarakat untuk dapat selalu berinteraksi dengan adanya masjid sebagai tempat ibadah dan untuk memperdalam pembelajaran agama Islam melalui aktivitas rutin yang dilaksanakan. Jadi, aktivitas dakwah di Masjid Peneleh ini memang sengaja menyesuaikan dengan kondisi masyarakat Peneleh yang notabene mayoritas adalah kaum Nahdliyyin yang tentu saja berpaham ablussunnah wal jama'ah.

Ketua Takmir Masjid Peneleh mengungkapkan bahwa keadaan masyarakat ketika ia masih kecil itu sangat heterogen sekali, terdiri dari berbagai macam suku, ras, agama, dan keyakinan. Akan tetapi, seiring berjalannya waktu saat ini mayoritas warga masyarakat sekitar Masjid Peneleh adalah kaum Nahdliyyin. Jama'ah untuk pengajiannya pun 75\% adalah warga sekitar, sedangkan sisanya sekitar $25 \%$ adalah jama'ah yang datang dari luar.Hal tersebut dikarenakan memang Masjid Peneleh diseting harus ada kedekatan dan interaksi secara langsung antara pengurus masjid, masjid sebagai tempat ibadah, dan masyarakat sekitar. ${ }^{23}$

Jadi, berdasarkan keterangan di atas dapat disimpulkan bahwasannya dakwah yang ada di Masjid Peneleh Surabaya ini banyak mencirikan unsur-unsur dalam paham Islam Nusantara. Hal tersebut dapat dilihat dari kitab-kitab yang dikaji hingga pemilihan subjek

\footnotetext{
${ }^{21}$ Chuck Williams, Manajemen (Jakarta: Salemba Empat, 2001), 9.

${ }^{22}$ Sofyan, Wawancara oleh Penulis, 08 April 2019.

${ }^{23}$ Sofyan, Wawancara oleh Penulis, 08 April 2019.
} 
dakwah atau komunikator dakwah yang merupakan mubaligh mubalighah yang berasal dari kalangan Pondok Pesantren. Hal ini tentu saja sesuai dengan strategi perencanaan yang diatur oleh takmir atau pengurus masjid yang memang sudah menyesuaikan dengan keadaan masyarakat sekitar yang mayoritas kaum Nahdliyyin. Selain itu, juga untuk mempertahankan ajaran turun-temurun dari para wali yang mensyiarkan Islam di tanah Jawa ini terutama Sunan Ampel yang memang dalam sejarahnya mendirikan Masjid Penelehsebagai media penyebaran ajaran Islam, dikarenakan kampung Peneleh pada zaman dahulu merupakan kampung yang ramai tempat bertemunya berbagai penjual dan pembeli dari berbagai daerah dikarenakan dekat dengan Kalimas yang merupakan jalur transportasi perdagangan pada saat itu.

\section{Strategi Perencanaan Komunikasi Dakwah Masjid Peneleh Surabaya dalam Tinjauan Struktural Fungsional Talcott Parsons}

Teori struktural fungsional menjelaskan bahwasannya masyarakat itu merupakan suatu sistem yang secara fungsional terintegrasi ke dalam bentuk keseimbangan. Talcott Parsons mengungkapkan bahwa yang menjadi pernyataan fungsional dalam suatu sistem di masyarakat dapat dianalisis, baik yang menyangkut dengan struktur maupun tindakan sosial. Berupa perwujudan nilai dan penyesuaian dengan lingkungan yang menuntut suatu konsekuensi adanya persyaratan fungsional. ${ }^{24}$

Pandangan Talcott Parsons mengenai empat persyaratan fungsional yaitu mengenai AGIL. ${ }^{25}$ Adaptation (adaptasi) merupakan suatu sistem yang harus menanggulangi situasi eksternal yang genting, sehingga sistem harus menyesuaikan dengan lingkungannya. Di mana sebagai personal atau masyarakat harus dapat mempertahankan diri dengan cara harus mampu dan dapat beradaptasi dengan lingkungan yang ada di masyarakat serta menyesuaikan lingkungan dengan diri sendiri. Penyesuaian diri mencakup upaya penyelamatan (secure) sumber-sumber yang ada di lingkungan, dan kemudian mendistribusikannya melalui sistem yang ada. Setiap masyarakat dituntut memiliki kemampuan untuk memobilisasi setiap sumber yang ada di lingkungannya sehingga sistem tersebut dapat berjalan dengan baik.

Goal Attainment (pencapaian tujuan) dalamsebuah sistem harus mendefinisikan dan mencapai tujuan utamanya. Pencapaian tujuan terkait dengan upaya menetapkan prioritas di antara tujuan-tujuan sistem yang ada, sertamemobilisasi sumber-sumber sistem untuk mencapai tujuan tersebut. Di mana sistem ini harus berusaha mencapai tujuan-tujuan itu yang sedari awal sudah dirumuskan secara terperinci. Fungsi dari goal attainment adalah untuk memaksimalkan kemampuan masyarakat untuk mencapai tujuan-tujuan kolektif mereka.

Integration (integrasi) merupakan sistem yang harus mengatur antar hubungan bagianbagian yang menjadi komponennya, tindakan koordinasi dan pemeliharaan antar hubungan unit-unit sistem yang ada. Sistem juga harus mengatur antar hubungan fungsi lain (A, G, L). Di mana dalam sistem ini harus mengatur hubungan-hubungan itu sebaik mungkin, agar di antara sistem dapat berjalan dengan semestinya.

${ }^{24}$ Dewi Wulansari, Sosiologi: Konsep dan Teori (Bandung: PT. Rafika Aditama, 2009), 174.

${ }^{25}$ Ian Crap, Teori-teori Sosial Modern (Jakarta: CV. Rajawali, 1992), 68.

JurnalKopis: Kajian Penelitian dan PemikiranKomunikasiPenyiaran Islam

Volume 03, Issue 02, Februari 2021 
Latency (pemeliharaan pola) yakni sistem harus melengkapi, memelihara, dan memperbaiki baik motivasi personal maupun pola-pola kultural yang menciptakan dan menopang motivasi-motivasi itu sendiri. Latency terkait dengan dua persoalan yang saling berkaitan, yakni pemeliharaan pola dan manajemen ketegangan. Pemeliharaan pola terkait dengan upaya bagaimana meyakinkan aktor yang berada di dalam sistem untuk menampilkan karakteristik yang tepat, baik yang berkaitan dengan motif, kebutuhan, dan perannya. Sementara itu, manajemen ketegangan berhubungan dengan ketegangan internal sistem dan juga ketegangan aktor di dalam sistem.

Apabila dikaitkan dengan fenomena strategi perencanaan komunikasi dakwah yang dilakukan oleh Masjid Peneleh, maka akan dapat dijabarkan sebagai berikut. Pertama, untuk unsur pertama yang harus ada dalam struktural fungsional adalah adaptasi. Adaptasi yang dilakukan oleh takmir atau pengurus Masjid Peneleh sangat tepat sekali, dikarenakan mengadopsi strategi yang digunakan oleh para Wali pada zaman dahulu, yakni dengan pendekatan kultural. Dengan pendekatan kultural tersebut pada akhirnya dakwah yang disampaikan akan sangat efektif dikarenakan sesuai dengan kultur atau budaya yang memang sudah ada serta berkembang di masyarakat. Sehingga pengurus atau takmir Masjid Peneleh tinggal meneruskan dan mengoptimalisasi programnya agar lebih efektif serta efisien.

Kedua, dalam pencapaian tujuan dakwahnya, Masjid Peneleh Surabaya mengkonsep isi pesan dakwah yang sesuai dengan kecenderungan serta latar belakang masyarakat sekitar Masjid Peneleh. Dikarenakan kawasan Masjid Peneleh ini mayoritas masyarakatnya kaum Nahdliyin, maka isi pesan dakwahnya juga bermuatan paham ablussunnah wal jama'ah, selain itu juga mengadopsi nilai-nilai yang bercirikan Islam Nusantara. Maka dari itu, untuk komunikatornya juga berasal dari orang-orang yang sepaham dan satu pemikiran keislaman.

Ketiga, dalam integrasi atau penggabungan berbagai elemen yang ada, Masjid Peneleh ini banyak mengintegrasikan komunikasinya dalam berbagai hal, misalnya dalam pengajaran dan pengurusan TPQ bekerjasama dengan Pondok Pesantren Tahfidz yang berada tepat di depan Masjid Peneleh Surabaya. Selain itu, untuk imam rowatibnya diintegrasikan antara sumber daya manusia masyarakat sekitar dan sumber daya manusia yang ada di Pesantren. Lebih lanjut Ketua Takmir Masjid Peneleh Surabaya menjelaskan bahwa untuk perencanaan program-program tersebut direncanakan setiap tahun. Jadi, takmir memprogram dalam satu tahun, jadi apabila di tengah jalan ada perubahan maka akan dievaluasi dan perbaiki satu tahun kemudian. Untuk pengelolaannya selain TPQ, juga terdapat Pondok Pesantren Tahfidz, meskipun berbeda yayasan namun ketua yayasannya sama. Sehingga selalu ada sinergi antara pondok dan Masjid Peneleh. Misalnya, dalam imam rowatib, mengajar ngaji TPQ, Masjid Peneleh banyak memanfaatkan sumber daya manusia yang ada di pondok tersebut. Jadi, khusus untuk jama'ah sholat dzuhur dan ashar imam rowatibnya dari pondok. Selebihnya mengoptimalkan sumber daya manusia yang ada di masyarakat sekitar. Misalnya untuk maghrib Ustadz Fatoni, Isya' Ustadz Yunus, dan untuk 
subuhnya Ustadz Fahruddin. Jadi, untuk sholat rowatib sendiri tidak sampai memanggil sumber daya dari luar. ${ }^{26}$

Keempat, dalam pemeliharaan pola ini harus selalu menjaga, memelihara, dan memperbaiki untuk meminimalisir terjadinya ketegangan dan kemungkinan buruk yang terjadi. Sehingga takmir atau pengurus Masjid Peneleh selalu menjaga komunikasi dan interaksi pada semua lini yang ada mulai dari hubungan antara takmir Masjid Peneleh dengan pengurus Pondok Pesantren Tahfidz, masjid sebagai tempat ibadah, dan juga masyarakat yang juga berperan aktif dalam mensukseskan program-program yang dilaksanakan takmir Masjid Peneleh dalam berbagai kegiatan dakwahnya. Tanpa adanya timbal balik dan partisipasi aktif dari anggota masyarakat, tentu proses komunikasi dakwah ini akan sulit berjalan dengan baik dan lancar. Oleh karenanya, takmir Masjid Peneleh selalu menjaga pola-pola yang telah dibangun selama ini agar proses dakwah yang direncanakan bisatepat sasaran sesuai dengan tujuan yang diharapkan.

\section{Kesimpulan}

Masjid Peneleh Surabaya merupakan salah satu masjid yang paling bersejarah di Kota Surabaya. Selain didirikan oleh Raden Rahmat (Sunan Ampel), masjid ini juga memiliki arsitektur bangunan yang sangat menarik. Dalam strategi perencanaan komunikasi dakwahnya, takmir Masjid Peneleh Surabaya mengambil komunikator atau da'i dari luar yang memang berkompeten dan sesuai dengan paham ablussunnah wal jama'ah. Dalam perancangan pesannya Masjid Peneleh meneruskan cara-cara dakwah yang dilakukan oleh para wali terutama Sunan Ampel. Isi pesan dakwah yang disampaikan yakni mengenai tafsir fiqih, tafsir hadist, tafsir riyadus sholihin, Ihya' Ulumuddin, dan al-Hikam. Sedangkan media yang digunakan dalam penyampaian dakwah ini masih menggunakan cara tradisional yaitu hanya dengan menggunakan media langsung atau bertatap muka. Dan dalam penentuan khalayaknya, Masjid Peneleh mentargetkan masyarakat sekitar yang mayoritas kaum nahdliyin, sehingga dakwah yang disampaikan pun banyak menggunakan ciri khas Islam Nusantara.

Berikutnya strategi perencanaan komunikasi dakwah yang dilaksanakan oleh Masjid Peneleh Surabaya apabila ditinjau menggunakan teori struktural fungsional Taloctt Parson adalah sebagai berikut. Adaptasi, dalam adaptasi ini takmir Masjid Peneleh menyesuikan budaya dan cara keberagamaan masyarakat sekitar agar dakwahnya mudah diterima. Dalam pencapaian tujuannya, takmir Masjid Peneleh Surabaya mentargetkan isi pesan dakwah dapat diterima dengan baik oleh mayoritas masyarakat yang hidup di sekitar Masjid Peneleh. Sehingga output-nya diharapkan dapat meningkatkan kesalehan ritual dan kesalehan sosial masyarakat. Dalam integrasinya, takmir Masjid Peneleh selalu menjaga interaksi dengan baik antara masyarakat, masjid sebagai tempat ibadah, dan Pondok Pesantren Tahfidz. Berikutnya dalam pemeliharaan polanya, Masjid Peneleh Surabaya selalu membagi sumber daya manusia dari masyarakat dan pondok pesantren tahfidz untuk berperan aktif dalam menghidupkan berbagai aktivitas dakwah yang terdapat di Masjid Peneleh Surabaya.

${ }^{26}$ Sofyan, Wawancara oleh Penulis, 08 April 2019.

JurnalKopis: Kajian Penelitian dan PemikiranKomunikasiPenyiaran Islam

Volume 03, Issue 02, Februari 2021 


\section{Daftar Pustaka}

Ayyub, Mohammad E. Manajemen Masjid: Petunjuk Praktis Bagi Para Pengurus/Penulis. Jakarta: Gema Insani Press, 2001.

Cangara, Hafied. Perencanaan dan Strategi Komunikasi. Jakarta: PT. Raja Grafindo Persada, 2014.

Crab, Ian. Teori-teori Sosial Modern. Jakarta: CV. Rajawali, 1992.

Effendi, Mochtar. Manajemen: Suatu Pendekatan Berdasarkan Ajaran Islam. Jakarta: Bharata Karya Aksara, 1986.

Ilahi, Wahyu. Komunikasi Dakwah. Bandung: PT. Remaja Rosdakarya, 2010.

Khairi, Halilul. Dinamika Pelaksanaan Urusan di Bidang Persandian Pemerintah Daerah. Jakarta: Yayasan Pustaka Obor Indonesia, 2017.

Kusuma, Ari Saputra dan Bayu Mitra Adhyatma. "Revitalisasi Masjid dalam Dialektika Pelayanan Umat dan Kawasan Perekonomian Rakyat," Jurnal Al-Idarah, (online), Volume 01, No. 01, 2017, ( raniry.ac.id/index.php/alidarah/article/view/1522, diakses 29 Oktober 2020).

Masibuan, M. Manajemen Dasar, Pengertian dan Masalah. Jakarta: Bumi Aksara, 2007.

Rue, G.R. Terry dan L. W. Dasar-dasar Manajemen. Jakarta: Bumi Aksara, 1996.

Sofyan. Ketua Takmir Masjid Peneleh Surabaya. Wawancara oleh Penulis. 08 April 2019.

Wibowo, Amien. "Strategi Komunikasi Dakwah (Strategi Komunikasi Dakwah Majelis Dzikir dan Sholawat Jamuro Surakarta)". (http://eprints.ums.ac.id/35975/). Surakarta: Universitas Muhammadiyah Surakarta, 2015.

Wijaya, Ida Suryani. "Perencanaan dan Strategi Komunikasi dalam Kegiatan Pembangunan". Jurnal Lentera, (online), Volume 18, No. 01, 2015, (https://journal.iain-samarinda.ac.id/index.php/lentera journal/article/view/428, diakses 29 Oktober 2020).

Williams, Chuck. Manajemen. Jakarta: Salemba Empat, 2001.

Wulansari, Dewi. Sosiologi: Konsep dan Teori. Bandung: PT. Rafika Aditama, 2009.

Yani, Ahmad. Menuju Masjid Ideal. Jakarta: LP2SI, 2001. 